\title{
J C Smuts and J L van Deventer: South African Commanders-in-Chief of a British Expeditionary Force
}

Ross Anderson •

\section{Introduction}

The campaign in East Africa that lasted from August 1914 to November 1918 was quite unlike those fought in Europe or the Middle East. Apart from the significant physical differences and the fact that British troops were usually in the minority, the East African Expeditionary Force had two South African officers as commanders-in-chief during the bulk of the active offensive operations. The first was Lieutenant General Jan Christiaan Smuts (February 1916 - January 1917), the noted politician, lawyer and thinker, while the second was Lieutenant General Sir Jacob (Jaap) Louis van Deventer (May 1917 - November 1918), an undeservedly forgotten. Although the two men had a long association in peace and war, their personalities, command style and ultimate achievements were very different. It is the aim of this article to examine the background to the war in East Africa, their tenure in the chief command, including the constraints under which they operated, and to assess their performance.

\section{The coming of war to Africa}

At the outbreak of war in August 1914, the balance of forces in East Africa reflected the relative importance of the colonies to their respective imperial powers - very little. The four empires involved, British, German, Belgian and Portuguese, had not seriously planned to fight in Africa and the few armed forces available were intended for the preservation of European rule, not for all-out war. ${ }^{1}$ Each maintained about 2,500 soldiers together with a similar number of armed police, usually scattered in company-sized detachments. They possessed rifles and a limited number of machine guns, but there was no modern artillery, headquarters, supply or transport system. Furthermore, each colony had its own interests and vastly differing levels of economic resources with which to pursue them.

Assessed objectively, neither side's colonies were of much strategic value in the world conflict. The loss of any territory, while damaging to imperial prestige, could hardly affect the strategic situation in Europe. Both German and British East Africa ${ }^{2}$ were economically

I am indebted to thank Professor Hew Strachan for his many helpful comments and suggestions on this paper. Crown copyright material in the Public Record Office is reproduced by permission of Her Majesty's Stationery Controller. Material concerning General van Deventer's Record of Service has been provided by the South African National Defence Force.

Hordern, Military Operations-East Africa, Nashville, Tennessee: 1990 (reprint of 1941 original), p. 559; CAB 8/5, CO No. 20794/10, No. 431 M "East and West African Protectorates Position in the Event of War with a European Power", dated 24 January 1911, Appendix II, p. 7; Boell, Die Operationen in Ostafrika, Hamburg: Walter Dachert, 1951, pp. 28 and 243; Campagnes Coloniales Belges, Bruxelles: Ministere de la Defense Nationale, 1925, I, pp. 25-26; In August 1914, the British had just under 2,400 soldiers and 3,200 armed police; the Germans had 2,700 soldiers and 2,200 armed police; the Belgians had 15,000 armed police in the Force Publique; and the Portuguese sent an expedition of 1,500 soldiers to Mozambique in 1914.

2 Their official titles were Deutsch-Ostafrika and the East African Protectorate respectively, but they were usually known as German and British East Africa. 
undeveloped, their internal communications, apart from railways, were almost non-existent, their settler populations were tiny and they consumed far more revenue than they had ever produced. Cut-off from the outside world by the power of the British Royal Navy, the German colony lacked the resources seriously to menace either its British-run neighbours or the Belgian Congo while in the south, Portuguese East Africa retained an ambiguous neutrality.

With its vast size, difficult terrain (their colony was over one and a half times the size of Imperial Germany) and few military resources, the Germans could only seriously threaten the Uganda Railway, the lifeline to both British East Africa and Uganda, which ran parallel to their northern border. In the west, although the region was densely populated, the prospects of invading heavily forested and low-lying Congo basin were poor, while in the undeveloped and thinly populated southern portion of German East Africa, little could be done against the British territories of Nyasaland and Northern Rhodesia. On the other hand, Britain could use its maritime superiority either to isolate the German colony or reinforce East Africa at will, although once ashore, its forces would be subject to the same set of difficulties as the Germans. In short, the Entente held a powerful strategic advantage, and it was clear that the fate of the African colonies would be decided in Europe and not the other way round.

\section{Initial British strategy and South African involvement}

War initially came to Africa not for reasons of expansionism, but for those of British imperial security. From the outset, the British put in place a strategy of protecting their maritime interests and attacking the German system of overseas communications without detracting from the efforts in the main theatre of war. ${ }^{3}$ In practical terms this meant the destruction of the German colonies' system of wireless transmitters as well as denying bases to their fleet. This policy was also attractive to the government as it could be largely achieved by amphibious operations and did not require the conquest of substantial inland territories. In order to maintain unity with its allies, the British had specifically ruled out acquiring territories for the purposes of imperial expansion, stating that all permanent decisions would be subject to any post-war peace conference. ${ }^{4}$ However, this high-minded declaration did not rule out the conquest of enemy colonies, as such prizes could be useful negotiating pieces. ${ }^{5}$ It also recognised, if only informally, that the self-governing dominions, such as South African and Australia, might have their own aspirations towards their German colonial neighbours.

The other European powers in Africa had their own views on the subject, but the British made it quite clear that their allies' offers of military assistance in East Africa were unwelcome. Expressed in diplomatic language, the Belgian, Portuguese and even French attempts to contribute contingents against the common enemy were rebuffed early in the war. ${ }^{6}$ This may be

3 Hankey, Lord, The Supreme Command, Vol 1, London: George Allen and Unwin, 1961, p. 168. French, David, British Strategy and War Aims, pp. 27-28. Oxford and Asquith, Earl of. Memories and Reflections 1852 - 1927, Volume II, London: Cassel and Company, 1928, p. 25.

4 CAB 21/3, Proceedings of a Sub-Committee of the Committee of Imperial Defence Assembled on the $14^{\text {th }}$ August, 1914", 14 August 1914. "...no formal proclamation annexing any such territory should be issued without specific instructions from His Majesty's Government, and further, that an agreement should be come to with our Allies to act on similar lines." ; French, British Strategy, p. 15.

Churchill, W S. The World Crisis 1911-1914, Volume 1, London: Thomas Butterworth Limited, p. 283.

6 MS Harcourt, Bodleian Library, Oxford, dep 507, Colonial Office Telegrams Circulated to the Cabinet August 1914 - August 1915. Telegram Secretary of State for the Colonies to the High Commissioner for South Africa, 22 September 1914 and telegram Secretary of State for the Colonies to the Governor East African Protectorate, 3 October 1914 for the Belgians; dep 507, Telegram, No 3 Secretary of State for the Colonies to Commissioner for South Africa, 27 August 1914 and dep 590 Foreign Office Print, 
attributed to British over-confidence in their own abilities to eliminate the Germans as a rival as well as a wish to deny other countries a claim in the potential spoils. Despite the pressing need for military victory over the Central Powers, imperial rivalries and colonial aspirations would remain significant factors throughout the war, and East Africa would be no exception.

However, this littoral strategy did not last very long in its pure form as other factors induced the British to invade German colonies shortly after the outbreak of the war. Subimperialism and local fears for security played their part in forming a more aggressive attitude. Togoland fell by the end of August, while colonial expeditionary forces were being prepared to attack the Cameroons in the north and German South-West Africa in the south. ${ }^{7}$ While these campaigns were to drag on much longer than initially expected, it was in East Africa, that this alteration to the initial British strategy was to have the most visible effects.

The involvement of the Union of South Africa in German South-West and subsequently German East Africa was outwardly puzzling. In fact, the presence of a large South African contingent, led by one of the country's foremost politicians and veteran of the Anglo-Boer War, may be considered remarkable given the traditional Afrikaaner hostility to British imperial actions. Yet while the Union of South Africa had only been formed in 1910 and many remained hostile to their new overlords, it must be remembered that the Boer republics had been founded on expansionism with the Great Trek being the best-known example. Leading politicians, most notably Louis Botha and Jan Smuts, viewed the neighbouring territories of German South-West Africa, British-run Rhodesia and Portuguese East Africa as attractive acquisitions for a Greater South Africa. Indeed there had been considerable frustration at the manner in which the Boers had been "hemmed-in" during the colonial expansion of the late nineteenth century. ${ }^{8}$ The outbreak of war had presented an unparalleled opportunity to advance these claims under the auspices of being loyal to Britain's cause.

The planned attack on German South-West Africa had been delayed by the outbreak of the Rebellion in October 1914. However, as soon as the dissident forces had been suppressed, the Prime Minister, Louis Botha, took personal command of the operations, with Smuts' assistance from Pretoria and later in the field. ${ }^{9}$ The threat of future risings and physical attack from that territory were used to justify the seizure:

"He [Botha] added however emphatically that the cost was worth incurring, if, as he believed, it would make any further rising impossible for the future, and if it secured by annexation the German territory from becoming, as it otherwise would, both a military and intriguing menace against South Africa."10

Smuts certainly agreed with Botha and had no intention of relinquishing any captured territory. ${ }^{11}$ German East Africa was a less obvious target for South African ambitions, separated as it was by the masses of the Rhodesias, Mozambique and Nyasaland from the

Telegram No 176, Sir Edward Grey to Mr Carnegie, 26 August 1914 for the Portuguese; CAB 21/3, Telegram Foreign Office to Sir F Bertie, 14 August 1914 and Andrew, Christopher and KanyaForster, France Abroad, London: Thames and Hudson, 1981, pp. 62-63 for the French.

7 French, British Strategy, pp. 27-28.

$8 \quad$ Hyam, Ronald. The Failure of South African Expansionism 1908-1948. London: Macmillan, 1972, pp. 23-24.

9 Strachan, The First World War To Arms, I, Oxford: Oxford University Press, 2001, pp. 554-555.

10 MS Harcourt, dep 471, Letter Buxton to Harcourt, 2 November 1914. This letter followed a meeting with General Botha.

11 MS Buxton, British Library, dep 9930, File September 1914, 24 September 1914, Letter Buxton to Harcourt. Smuts is quoted as saying, "if the Union Government were successful in these operations, and conquered the territory, it would be impossible in the circumstances to relinquish it to Germany," 
northern tip of the Transvaal. However, Smuts saw it as a useful bargaining tool with the Portuguese and hoped to swap the its southern area in exchange for the southern portion of Portuguese East Africa:

"The Union Govt. are of course anxious to put out a claim to some part of Port: E.A. and think this an opportunity to do so, and the above re-arrangement of territory is Smuts special pet idea." 12

Such an exchange would provide first class ports for an enlarged South Africa and remove a rival power from the scene. ${ }^{13}$ It also had the merit of coinciding with the British belief that Portugal was unfit to be a colonial power and might welcome an expansion of its colonial interests under the South African banner. Furthermore, as the hard-pressed British and Indian Armies were unable to spare significant reinforcements for the campaign, a strong South African contingent would be welcomed on military as well as political grounds.

The evolution of the East Africa campaign is a story in itself, but it evolved from the relatively simple plan of destroying coastal wireless facilities and denying the use of Dar-esSalaam as a port, into an ill-judged attempt to seize the whole of German East Africa with two lightly equipped brigades of the Indian Army. The decision to attack was made on a number of erroneous assumptions that arose through a combination of poor planning, interdepartmental rivalries and a lack of firm leadership; it was to have long-lasting effects on the campaign.

The result was the disastrous attempt to land at Tanga in early November $1914 .^{14}$ Decisively defeated by the numerically inferior German forces, the British retired to British East Africa where, on the orders of Lord Kitchener, the War Secretary, they went over to the defensive. He correctly realised that East Africa was a strategic backwater and refused further substantial reinforcements as he generally opposed any moves to diminish the main effort on the Western Front. ${ }^{15}$

This defensive policy would hold true for the better part of 1915. The forces in British East Africa suffered not only from insufficient numbers, but also widespread sickness from malaria and poor morale. This, and the lack of an energetic commander, sapped their effectiveness and the year was largely spent in static warfare, with both sides relying on small patrols and raids to disrupt their opponents, while simultaneously trying to build up their own limited forces. The one major initiative that was approved by Kitchener was the pushing of a spur of the Uganda Railway close to the British-German border, a factor that would be crucial in any offensive operations. ${ }^{16}$

Despite Kitchener's views and the dismal failure at Tanga, influential voices were proposing a more aggressive strategy in East Africa as early as December $1914 .^{17}$ This, coupled with the War Office's reluctance to provide significant reinforcements there, led to a change in attitude amongst some members of the Government. By January 1915, official

\footnotetext{
12 MS Harcourt, dep 472, Letter Buxton to Harcourt, 18 May 1915; MS Buxton, dep 9930, File May 1915, 15 May 1915, Letter Buxton to Harcourt.

Hyam, South African Expansionism, pp. 26-28

A fuller account of the political background and of the battle of Tanga itself is at Anderson, Ross, "The Battle of Tanga 2-5 November 1914", War in History, Volume 8, No. 3, 2001, pp. 294 - 322. WO 33/714, European War Secret Telegrams Series B, Volume 1, $31^{\text {st }}$ July 1914 - $31^{\text {st }}$ January 1915, London: War Office, 1915. No. 1522, 4 December 1914, Telegram 2343, War Office to General Wapshare.

16 WO 33/714, European War Secret Telegrams Series B, Volume I, No. 23, 15 February 1915 , Telegram S215, Wapshare to War Office.

17 Hankey, The Supreme Command, Volume I, p. 249.
} 
meetings were underway in London with the Belgians trying to determine the best form of military co-operation, while unofficial feelers were being put out to South Africa. ${ }^{18}$ Despite British reluctance to bring Portugal into the war, the Governor of Nyasaland was authorised to seek their military assistance as a measure of last resort. ${ }^{19}$

The formation of the first coalition government in May 1915 also increased the pace of change. The new, non-Liberal, ministers had a different outlook on the war and relationships within the government deteriorated. ${ }^{20}$ As the year progressed, the shells crisis, the failure to preserve Serbia's independence and the stalemate at the Dardenelles led to growing disenchantment with Asquith's leadership and the conduct of military strategy. However, the success of the South African campaign against German South-West Africa and the positive manner in which the newly created dominion was supporting Imperial policies encouraged the British Cabinet to seek victory elsewhere. In this, they were ably supported by the Governor General, Lord Buxton, who was active behind the scenes in promoting a forward military policy with leading ministers. ${ }^{21}$ The South African Government needed little convincing, particularly Smuts who already had the spoils firmly in mind:

"...But they [the British Government] now practically intimate that in future German East Africa will be our destination. If that country were conquered by us, we could probably effect an exchange with Mozambique and so consolidate our territories south of the Zambesi and Kunene...,"22

Smuts' ambitions, however, were getting ahead of themselves as the fighting in German South-West Africa was far from over. It was the Prime Minister, Botha, still engaged in personally directing the campaign at the front, who was more cautious, prudently preferring to finish off one campaign before starting another. ${ }^{23}$

Despite this, and as early as May 1915, speculation reached a point that the Government felt obliged to issue a press statement stating that no decision had been made about sending troops to Europe or elsewhere in Africa. ${ }^{24}$ Furthermore, as that campaign wound down in July 1915 , a new and difficult problem arose, that of winning the required General Election. The Botha government was under heavy pressure from the Nationalists and the Afrikaaner population was split. ${ }^{25}$ Ministers were seriously concerned about the effects of sending away so many potentially friendly voters before the election:

"The next Election is the most critical this country probably will ever have to face. It has not been possible to prevent the First Brigade from being formed, and that they are leaving before the Election takes place; but the Government are extremely anxious to do nothing that would add further to the disenfranchisement of voters.

MS Harcourt, dep 583, Kidston to Sir Edward Grey, 4 January 1915.

MS Harcourt, dep 507, 14 January 1915, Telegram Secretary of State for the Colonies to Governor of Nyasaland.

Turner, British Politics, pp. 62-63; French, British Strategy, pp. 100-102; Guinn, British Strategy, pp. $84-85$, is now dated but still of some value.

MS Harcourt, dep 507, 14 April 1915, Telegram, Governor General of South Africa to Secretary of State for the Colonies; See dep 471, 472 and 507 for numerous examples of the discussions between Buxton, Botha and Smuts.

Hancock, Keith Sir, and Poel, Jean van der. Selections from the Smuts Papers Volume III June 1910 November 1918, Cambridge: Cambridge University Press, 1966; 30 August 1915, Letter Smuts to J X Merriman, p. 310.

MS Buxton, dep 9930, File May 1915, 25 May 1915, Telegram D 166 Smuts to Buxton citing 22 May 1915, Telegram B 45 Botha to Smuts.

MS Buxton, dep 9930, File May 1915, 27 May 15, Press Cutting Cape Argus.

Meintjes, Johannes. General Louis Botha, London: Cassell, 1970, p. 273. 
Besides, in the uncertain state of politics they do not want to move in the matter of an East African Contingent until after the Election. Both the Contingent itself, and the financing of it might be used as points against them electorally." ${ }^{26}$

With the election set for October 1915, no outward preparations could be made until the last quarter of the year and it would take several months to recruit, equip and train any contingent. In the interim, nothing was publicly announced about South African participation in East Africa, as it would almost certainly have been a vote-loser in a close run contest. The British Cabinet realised the threat posed by Hertzog's Nationalists and wanted Botha's South African Party to be returned to power; accordingly, London heeded Lord Buxton's advice and refrained from public pressure. ${ }^{27} \quad$ For some time Buxton had believed that the passive, defensive strategy was failing to protect Northern Rhodesia and Nyasaland adequately, and had been pressed the Colonial Secretary to take the offensive. ${ }^{28}$ Despite War Office opposition, Bonar Law agreed with Buxton's assessment:

"The position in East Africa and surrounding districts is of a nature to cause the greatest anxiety...it would be of the greatest possible advantage to send a large enough force to conquer German East Africa once and for all., ${ }^{29}$

By late 1915, the British Cabinet was divided into two main factions with strongly opposed views on strategy, the management of the war effort, and conscription. Notably, there was strong opposition to further offensives on the Western Front and some ministers sought to find alternative theatres in which to achieve strategic success. ${ }^{30}$ Furthermore, Lord Kitchener had lost the confidence of his civilian colleagues who responded by scheming to diminish his powers. $^{31}$ One area of contention was East Africa, where Kitchener had maintained his opposition to any further offensive action while keeping its reinforcements to the bare minimum required.

Finally in November 1915, when he had been deliberately sent away on an inspection of the Dardenelles by the Cabinet, his opponents struck. Using a series of pessimistic and alarmist reports from the general in command in East Africa, the CIGS produced an appreciation that called for at least 10,000 reinforcements and a more active stance. ${ }^{32}$ In this he was supported by his Director of Military Operations, who later admitted to using Kitchener's absence as an opportunity for going against his express wishes. ${ }^{33}$

The General Staff did this with the knowledge that there was broad support for the scheme. ${ }^{34}$ Indeed, the King had taken a personal interest in the matter for some time and had

26 MS Buxton, dep 9930, File August 1915, 11 August 1915, Letter Buxton to Bonar Law.

27 MS Buxton, dep 9930, File August 1915, 19 August 1915, Letter Buxton to Asquith; 28 August 1915, Telegram Buxton to Bonar Law.

28 WO 33/714, European War Secret Telegrams Series B, Volume 1, No. 163, 10 April 1915, Telegram 3970, War Office to Buxton. Yorke, Edmund James, A Crisis of Colonial Control: War and Authority in Northern Rhodesia, 191919, Cambridge University PhD thesis, 1983, p. 132. Cites Bonar Law to Buxton, 3 September 1915. Turner, John, British Politics and the Great War Coalition and Conflict, 1915-1918, New Haven: Yale University Press, 1992, pp. 68-69; French, British Strategy, p. 159.

French, British Strategy, pp. 160-161.

WO 106/310, "The Military Situation in East Africa", CIGS 8 October 1915. In this report, General Sir A J Murray cited General Tighe's Telegram 322 of 2 August 1915, his despatch of 31 July 1915, and his Telegram 325 of 14 August 1915.

33 Callwell, Major General Sir C E, Experiences of a Dug-Out 1914 - 1918, London: Constable, 1920, pp. 178-179.

34 Gilbert, Martin, Winston S Churchill, III, Companion II Documents, London: Heinemann, 30 November 1916, Letter Curzon to Churchill, p. 1290. 
had his Private Secretary write to Bonar Law about the need to involve the South Africans in German East Africa. ${ }^{35}$ The Colonial Secretary needed little convincing as he had long welcomed such assistance and had been carefully negotiating with the South African Government through the Governor General for some time. ${ }^{36}$ Furthermore, the victory in October, albeit with a reduced majority, of Botha's South African Party, had cleared the main obstacle to an offensive there.

In the circumstances, the CIGS then produced a memorandum advocating an attack against German East Africa, using mainly South African troops, in order to enhance Britain's position at the end of the war. ${ }^{37}$ On his return to Britain, Kitchener wasted little time before weighing into the proposal, stating:

"This scheme for offensive operations in the centre of Africa is, in my opinion, a very dangerous project in the present state of the war...The general military policy now advocated, may therefore, lead us to place South African troops in positions where they will be liable to disaster, from which we will not be able to extricate them, as our troops will be fully engaged elsewhere. I think that the recent example we have had of similar proceedings based on wrong premises in Mesopotamia should teach us to be cautious in undertaking similar operations of this nature..." 38

Nevertheless, such was Kitchener's weakened position that the War Committee endorsed the new offensive strategy on 28 December 1915, having gained the support of General Sir William Robertson, the newly-appointed CIGS a few days earlier. ${ }^{39}$ It was a vast and ambitious project with the British planning to attack from British East Africa in the northeast and from Northern Rhodesia and Nyasaland in the south-west, with the Belgians advancing from the Congo in the west. The prospective Commander-in-Chief, General Sir Horace SmithDorrien had identified many of the salient difficulties of campaigning there, but nevertheless, it is clear that the politicians expected a quick and easy victory. ${ }^{40}$ The scene was now set for a major struggle in the heart of Africa.

\section{Conditions of fighting in East Africa}

Before attempting to assess Smuts' and van Deventer's performance, it is essential to outline the conditions and constraints under which they fought. German East Africa was sparsely developed and lacked almost all of the facilities taken for granted in Europe. For the most part, it was covered in dense bush that ranged from tropical jungle with swamps to forested mountain ranges to undulating parched scrubland. Physical communications were generally

MS Buxton, dep 9930, File August 1915, 13 August 1915, Letter Lord Stamfordham to Buxton.

MS Buxton, dep 9930, File May 1915, 9 May 1915, Telegram Buxton to Harcourt; 11 May 1915, Telegram Harcourt to Buxton; 19 May 1916, Letter Bonar Law to Buxton; File August 1915, 9 August 1915, Telegram Bonar Law to Buxton.

CAB 22/3, "An Appreciation by the General Staff on the Situation in East Africa", 10 December 1915. It foresaw about 15,000 reinforcements, of whom 14,000 were South Africa and 1,000 were Indian, joining the nearly 15,000 troops already in-theatre.

CAB 22/3, "Minute by the Secretary of State for War", appended to the General Staff Appreciation, 14 December 1915; CAB 22/3, War Committee Meeting of 15 December 1915.

CAB 22/3, War Committee Meeting of 28 December 1915. Robertson's agreement was contained in the "CIGS Note" of 23 December 1915.

WO 106/310, "Appreciation on the Situation in East Africa", General H L Smith-Dorrien, 1 December 1915, pp. 3-4. Smith-Dorrien put great emphasis on the need for careful and thorough preparation on account of the climate and endemic diseases. He thought that the Government believed that GEA could be completely subjugated by April 1916, but warned that no decisive result could occur before July or August 1916. 
very primitive, apart from two unconnected railways and movement was usually limited to narrow and unsurfaced tracks that wound their way through forest, bush and jungle. With virtually no roads, this forced the combatants to move in columns, most often in a single file that stretched out over many miles. Inter-communication between columns was often impossible and formations could pass within a mile of each other and remain undetected. ${ }^{41}$

Powerful, wide and unbridged rivers, rocky outcrops and swamps also caused timeconsuming diversions while navigation itself was extremely problematic owing to the virtually non-existent state of survey and consequently inaccurate maps. It was frequently necessary to march cross-country on compass bearings with distances measured only by human pacing and timing. If these difficulties were not enough, dense vegetation often reduced visibility to a few metres or less, especially when moving through bamboo thickets or elephant grass. Climate played its part, as for much of the year, there was insufficient precipitation to support grazing while for remainder there was a superabundance of water that impeded movement, made life generally miserable and promoted sickness. In the dry season, the dust raised by the marching columns or vehicles covered everything and enveloped the troops in a thick cloud, while in the wet, heavy continuous rain and mist made observation very difficult. The temperature ranged from very hot, with humid and arid extremes, in the lowlands to cold and damp in the mountains. ${ }^{42}$

Apart from natural obstacles, movement was slow as it took several hours just to get the leading elements sufficiently far ahead of the main body for it to set off. Furthermore, the fighting troops were inevitably accompanied by a long line of civilian carriers, who usually matched or exceeded their own numbers. Frequently, too they were followed by large masses of pack and slaughter animals. Behind them, the lines of communications troops would be straining to maintain touch with a combination of carriers and motor vehicles in order to push the required quantities of food, ammunition, and equipment to the forward areas. $^{43}$

Finally, disease was to prove decisive both for humans and animals. Malaria was the single greatest threat faced during the campaign, followed by dysentery, pneumonia and typhoid. The sickness rates for humans in East Africa were amongst the highest in the war while those for animals were nearly $100 \%$ owing to the tsetse fly, horse-sickness and rinderpest. ${ }^{44}$ All in all, East Africa was one of the most difficult places in the world in which to conduct military operations. Survival, let alone victory, would require the highest standards of planning and hygiene.

\section{Smuts' appointment}

With the plan to invade German East Africa approved by the British Cabinet and the South African Government providing the bulk of the contingent, General Smith-Dorrien was expected to lead the force. However, he had fallen dangerously ill of pneumonia during the long sea

Sheppard, Brig Gen S H. "Some Notes on Tactics in the East African Campaign", Journal of the United Service Institution of India, Vol XL VIII, No. 215, April 1919, pp. 142-143.

42 Hordern, Military Operations East Africa, pp. 12-14; Orr, Col G M, "Some Afterthoughts of the War in East Africa, 1914-1918", Journal of the Royal United Services Institute, Vol LXIX, 1924, pp. 696-697. Ridgway, Brigadier General R T, "With No 2 Column", Army Quarterly, V, pp. 13-14. Blenkinsop, General Sir L J and Rainey, Lt Col J W. History of the Great War based on Official Documents. Veterinary Services, London: HMSO, 1925. p. 417; Mitchell, Major T J. History of the Great War; medical services. Casualties and Medical Statistics of the Great War, Nashville, Tennessee: , The Battery Press, (Reprint of 1931 original).
} 
journey and despite a recovery was deemed medically unfit to take up his command. In the circumstances, the British offered the appointment a second time to Smuts in February 1916. He had been approached prior to Smith-Dorrien's nomination, but had declined citing his parliamentary and political responsibilities. ${ }^{45}$ With the government now re-elected, his commitments became less demanding and he agreed to take up the post of commander-in-chief of the East African Expeditionary Force. This was a highly unusual appointment, with a colonial officer in supreme command of imperial troops, but it received the assent of both Lord Kitchener and the War Committee on 3 February $1916 .{ }^{46}$ It was to be a fateful and far-reaching decision.

The appointment of a politician, although a major general in the Union Defence Force, was extraordinary to say the least. It partly reflected political disillusionment with the Army's senior leadership; Lloyd George, Bonar Law and Churchill believed that the 'inspired amateur' could do better than what they saw as the narrow-minded professional officer corps. ${ }^{47}$

Smuts had also helped manoeuvre himself into the position. As has been seen, he had been instrumental in instigating an aggressive policy in East Africa as well as pushing for a large South African contingent. Although the war in German South West Africa had been far from popular in some Afrikaaner circles, he judged that the benefits of supporting Britain in East Africa would outweigh the unpopularity of a new campaign. For its part, the British Government was anxious to support the Botha government; it had suppressed a major rebellion before conquering one enemy territory and was now actively supporting the Imperial war effort in Europe as well as Africa. In the circumstances, Smuts' appointment, with his Cambridge education and connections, Anglo-Boer War service and more recent experience seemed to be a good one.

On the other hand, there were serious limitations to Smith-Dorrien's successor. He was not a professional soldier and he lacked experience of higher command in war. ${ }^{48} \mathrm{He}$ had been a very successful leader of a commando in the Anglo-Boer War, but his troops had seldom numbered more than 300 and the fighting was in friendly and fertile territory. Subsequently, he had served for some time as second in command in the campaign to conquer German South-West Africa, leading a subsidiary column from the south. However, while arid, that country was reasonably favourable for the use of mounted troops and had few of the deadly tropical diseases that plagued the East Coast. Importantly, the German defenders there were not particularly well-led and conducted a mainly passive defence that succumbed easily to Botha's tactics (and logistical planning). ${ }^{49}$ Now, Smuts was being called upon to lead over 50,000 soldiers of many nationalities and languages through extremely difficult and often unmapped terrain while battling a harsh climate and a host of deadly diseases. Apart from operational and tactical skill, his appointment also required a

MS Buxton, File February 1916, 1 February 1916, Telegram Buxton to Bonar Law; 8 February, Telegram Buxton to Bonar Law; Hancock and van der Poel, Selections from the Smuts Papers, III, 29 November 1915, Letter Smuts to A B Gillett. CAB 22/3, War Committee Meeting of 3 February 1916. Gilbert, Martin, Winston S Churchill, III, London: Heinemann, 12 November 1915, Letter Bonar Law to Asquith, pp. 565-566.

MS Buxton, Semi-Official Letter File, 12 February 1916, Smith-Dorrien to Buxton. Despite the public announcements stating that he had recommended Smuts to be his replacement, he privately made it clear that this was not the case. "Concerning General Smuts' powers as an up to date General I know nothing and I certainly should not have selected him had there been time to get a General who had devoted His life to War from Home." 
firm grasp of administration and supply which had been shown to be so important in previous African campaigns.

Smuts's position was also not made easier by his position as a politician and leading government minister. It was unavoidable that politics would play an important role in his decision-making, be it the appointment of officers, selection of strategy or the issuance of communiqués. With the Prime Minister, Botha, under heavy pressure from the Nationalist party, Smuts was acutely conscious of the dangers of a large casualty list. ${ }^{50} \mathrm{He}$ was also well aware of the need for success, as any setback would be used to attack and possibly weaken the government.

\section{Smuts' aims and intentions}

On taking over the chief command from Smith-Dorrien, Smuts received a copy of his instructions, which read in part:

"is to undertake an offensive defensive with the object of expelling the enemy from British territory and safeguarding it from further incursion. The decision as to the ultimate scope of the offensive operations to be undertaken against German East Africa after the rainy season should be postponed until General Sir Horace SmithDorrien has reported in light of the experience gained before the rainy season." ${ }^{, 51}$

However, Smuts had no intention of waiting for the dry weather and had been pressing for an early advance well before his appointment as commander-in-chief. He had prevailed upon the Governor General to overrule Smith-Dorrien's plans to start after the end of the rains in late May, claiming that delay would have deleterious effects on morale, recruiting and the health of the troops. ${ }^{52}$ In this he was successful, obtaining the War Committee's permission to start before the rains, provided that he was confident of success. Accepting the appointment on 5 February 1916, he sailed for East Africa shortly thereafter, arriving at Mombasa on 19 February. He was then briefed by incumbent General Officer Commanding, which was followed by a rapid reconnaissance of the areas likely to be involved. Despite the shortness of time for detailed consideration of the situation and his lack of familiarity with the region, he signalled to London on 23 February that he wished to undertake an immediate offensive, receiving approval two days later. ${ }^{53}$

This sense of over-riding haste was to be typical of Smuts' time in command. While it was interpreted as part of his implacable willpower and desire for success, it can also be seen as part of his lack of understanding of the situation. He had pressed for an accelerated offensive timetable before he had been given all of Smith-Dorrien's campaign papers or had inspected the terrain. ${ }^{54} \mathrm{He}$ made up his mind to attack in less than four days in country, of which the better part of two were needed for travel, and before the all-important transport

50 Hancock and van den Poel, Selections from the Smuts Papers, 13 April 1916, Letter Botha to Smuts, p. 356; Meinertzhagen, Army Diary, p. 166.

$51 \quad$ Hordern, Military Operations East Africa, p. 222.

52 MS Buxton, File February 1916, 1 February 1916, Telegram Buxton to Bonar Law.

53 Smuts, Lt Gen J C, Military Despatches from the Commander-in-Chief, East Africa Forces, Despatch dated

April 1916, published in the London Gazette" Supplement", No. 29630 of $20^{\text {th }}$ June 1916, p. 187. Henceforth Smuts, Despatch $I$.

$54 \quad$ MS Buxton, File February 1916, 7 February 1916, Brigadier General Simpson-Baikie to Buxton. The relevant files were only despatched on that date while the request for an accelerated attack was sent to London on 1 February. 
arrangements were put in place. Furthermore, his own troops were still in the process of arriving (one brigade would not arrive until after the opening of the offensive) and had had very little time for acclimatisation or reconnaissance. Most significantly, he had already decided that his mounted troops would play a leading role through a country that was known to be infested with the tsetse fly with its fatal effects on all domestic animals. ${ }^{55}$ This was not just relevant to the mounted brigades, but also to the overwhelmingly animal-drawn supply system. Ironically, his predecessor had specifically requested that only the front line units have mules with the remainder equipped with motor vehicles. ${ }^{56}$ Smuts chose not to wait or rectify this critical weakness.

\section{Smuts' style of command}

Furthermore, the unique combination of Smuts' previous military experience, his political role and territorial aspirations together with his personal characteristics gave him a decided approach to campaigning. In order to achieve his ambitious ends, he planned to use manoeuvre as the means of defeating the Schutztruppe. He was opposed to fighting heavy battles and preferred to use limited frontal holding attacks supported by wide turning movements by highly mobile mounted columns aimed at hitting the enemy's flanks and cutting off his escape. ${ }^{57}$ He counted on their unexpected appearance in the rear areas and withdrawal routes to cause disruption and disintegration. These tactics had worked well on the South African veldt and in the bush of South-West Africa, but failed to consider the rather different conditions of East Africa. ${ }^{58}$

Above all, he wanted to conquer territory and, despite his pronouncements, he never appears to have been really interested in defeating the Germans in pitched battle. This was not due to physical fear, as he was personally brave and was frequently in or about the front line. $^{59}$ The quality of his intellect stood out and he understood manoeuvre very well; his difficulties came when it came to pressing the fight home and translating his grand intentions into attainable orders.

His emphasis on speed left little time for accurate reconnaissance, making the locating of the exact position and depth of the enemy's positions difficult. For the flanking column, even just finding the defences was a major concern and they often relied upon the sounds of firing in order to close in for the fight. Liaison by telephone or runners between friendly columns was only possible once the objective was near, but these methods were hindered by the activity of the German defenders who often captured runners and cut communication cables. While a wireless transceiver was deployed with each column, they were insufficient in number as well as being too heavy and unreliable to be usable in controlling a tactical battle.

Despite these disadvantages, Smuts was to apply his methods repeatedly, seemingly regardless of the terrain, the weather or the state of his troops. However, at this point, it is

\footnotetext{
55 Orr, "Some Afterthoughts on the War in East Africa", p. 697.

56 WO 106/310, "Appreciation on Situation in East Africa", General H L Smith-Dorrien, 1 December 1915 , p. 4.

57 Smuts, Lt Gen J C, Military Despatches from the Commander-in-Chief, East African Forces, Despatch dated $27^{\text {th }}$ October 1916, published in the London Gazette" Supplement", No. 29906 of $17^{\text {th }}$ January 1917, pp. 121, 125, and 128-129. Henceforth, Smuts, Despatch II. These tactics were frequently used by van Deventer and other South African commanders as well. Strachan, The First World War, I, p. 605.

59 Meinterzhagen, Army Diary, p. 166.
} 
important to distinguish the concept of the local flanking attack, which was used to great effect by both sides, and which seldom extended more than several thousand yards from the centre of the battle, from the extended moves favoured by Smuts. These wide turning moves frequently involved marches of up to 10 to 30 miles parallel from the enemy positions before cutting into the rear area. The results of these moves were frequently much less effective than desired, despite his claims to the contrary.

That Smuts would be unfamiliar with the British Army's methods was expected and an experienced officer was supplied as his Chief of General Staff (CGS), A R Hoskins. However, while taking over the bulk of Smith-Dorrien's staff, Smuts had insisted on a number of changes in key appointments. The most important substitution was of Hoskins for the South African J J Collyer as CGS. As this was by far the most influential staff post, Smuts was within his rights in making such a decision, but it was at the cost of losing a highly experienced professional officer who had been Inspector General of the King's African Rifles for one who had only served in South Africa. Matters were not helped by the relative inexperience of many of the more junior staff officers, particularly in the administrative branches. ${ }^{60}$ While Collyer was able enough in purely operational matters, he never seemed to grasp of the importance of underpin Smuts' plans with a sound logistical basis. The importance of this weakness would become glaringly apparent in late 1916 .

The bringing together of British and Imperial forces, under South African command was unprecedented and led to rivalry and friction particularly at the higher levels. While Smut's qualities of leadership and decisiveness were appreciated, considerable doubts over his tactical abilities emerged, particularly from the professional British officers in the force. Indeed, there was some speculation about the motives of Smuts and the other senior South African commanders, most of whom were close associates in private life and were often involved in politics at home. A number of British officers believed that the inability to catch and defeat the Germans in pitched battle was due to a distinct reluctance to incur heavy casualties and therefore opprobrium with the electorate. ${ }^{61}$ This sentiment lasted throughout Smut's tenure in command and contributed to ill-feeling between the two groups and did little to promote co-operation.

Unhappiness with the commander-in-chief was not limited to British Army officers. Smuts had made himself deeply distrusted by a considerable segment of the population, both Afrikaners and English. ${ }^{62} \mathrm{He}$ was admired for his intellect and energy, but was also aloof and remote, lacking Botha's personal magnetism. He was conscious of his superior mental agility and adroitness and this confidence often came across as arrogance or aloofness. He was seldom at his main headquarters, preferring to be forward with a few, trusted officers. Smuts was not a man for discussing matters with his subordinates or seeking advice. ${ }^{63}$

\section{Smuts' operational achievements}

Smuts' period of operational command may be divided into four main phases; the first comprised the attack on the Kilimanjaro position and the subsequent advance to Kondoa

$60 \quad$ Crowe, General Smuts' Campaign, pp. 4 and 7.

61 Meinertzhagen, Army Diary, pp. 198-200; CAB 45/44, Colonel Fendall's Diary, Entry for 29 August 1916; Crowe, General Smuts's Campaign, pp. 6-7 is the most tactful.

62 MS Harcourt, dep 474, 7 May 1915, Letter Buxton to Harcourt, and 17 May 1915, Letter Buxton to Harcourt; Reitz, Deneys, Trekking On, London: Faber \& Faber, 1933, pp. 66-67 and 105-106.

63 CAB 45/44, Colonel Fendall's Diary, Entry 12 October 1916 MS Buxton, File June 1915, 6 June 1915 , Letter Buxton to Bonar Law. 
Irangi (March to April 1916); the second was the push south to the Central Railway (May to August 1916); the third was the drive to and halt along the Mgeta River (September to November 1916); and the last was the combined advance that aimed to clear the Rufiji River (December 1916 to January 1917).

During the first phase, and in his desire to initiate operations before the start of the rainy season, Smuts adopted the bulk of his predecessor's plan. He intended to seize the Kilimanjaro area before the rains with in order to conduct his main advance in June. ${ }^{64} \mathrm{He}$ deployed about 25,000 soldiers as against the defenders approximately 5,000 rifles. $^{65} \mathrm{He}$ duly launched his advance against the German positions on 5 March with a division marching around Mount Kilimanjaro and the remainder setting off two days later headed west for the gap between there and the Pare Mountains. The aim was to use his superior mobility in the form of a South African mounted brigade to lever the Germans out of their forward positions and then to clear the route with the infantry brigades.

The move succeeded in taking ground, but von Lettow was able to escape largely unscathed. Furthermore, it revealed a number of weaknesses in both the leadership and organisation of the East Africa Force that could not be rectified during battle. The

fighting continued until the rains broke on $23 \mathrm{March}$, with the British taking possession of the villages of Kahe, Moschi including its railhead, and Aruscha with the Germans now holding the Pangani Valley along the line of the Usambara Railway.

As the roads began to dissolve and the area of operations became a quagmire, Smuts deployed the bulk of his troops onto the high ground in order to avoid the worst effects of the season. ${ }^{66}$ Both sides had lost heavily and an operational pause seemed essential, especially as the transport situation was rapidly becoming very difficult.

However, Smuts was impatient and sought even greater prizes. He saw the German retirement along the Pangani as a major error, believing it left the direct route to the interior, from Aruscha via Kondoa Irangi, open and undefended. Here, based on the advice of settlers who claimed that the rains did not affect the interior as much as they did the Kilimanjaro area, he made a momentous and far-reaching decision. ${ }^{67}$ It was to send a division forward nearly 200 miles to seize Kondoa Irangi to exploit the absence of German troops there.

After a brief reorganisation and despite the pouring rain and disintegration of the few roads, the General van Deventer's mounted troops left Aruscha at the end March, followed by the infantry. After a few incidents, Kondoa Irangi was reached on 17 April, with the troops having moved in appalling conditions and suffering severely from lack of food. While it was indeed a surprise move, by the end of April the troops there were in a desperate state. The bulk of the horses had either died or were dying from the effects of the tsetse fly while the soldiers were in clothed in rags unprotected against the weather and suffering heavily from malaria. Supplies were completely inadequate and could only arrived with the greatest of efforts. By early May, the division had less than 3,000 effectives and many of those were suffering from malaria, exposure and malnutrition. ${ }^{68}$

Smut's strategic thrust, already blunted by the elements, was incapable of further forward movement. Now, it was von Lettow's turn to counter with the unexpected; by early

\footnotetext{
64 Smuts, Despatch I, p. 189; Hordern, Military Operations East Africa, p. 234.

65 Hordern, Military Operations East Africa, pp. 259-260.

66 Hordern, Military Operations East Africa, pp. 252-259; Crowe, p. 109

$67 \quad$ Smuts, Despatch II, p. 107;

68 Hordern, Military Operations East Africa, pp. 274-276.
} 
May he had moved the bulk of his troops from the Pangani to Kondoa Irangi by early May. ${ }^{69}$ Although he was unable to dislodge the South Africans, the way forward was effectively blocked.

Smuts' pressure for an early advance before the rains only achieved 18 days of general campaigning and a foothold in enemy territory. His plan to seize Kilimanjaro seemed a reasonable objective, but ignored two factors of importance. The first was that only half his troops had arrived with relatively little collective training or experience of bush fighting and the second was that the climate of the uplands of British East Africa was much healthier than that of German East Africa, particularly in the rains. Preparations would have been much more thorough and the troops fitter and better trained had they waited there until May, but Smuts had already staked too much for such a delay to be considered.

He had successfully broken through the German defences and rightly consolidated for the rains. However, the sending of a division to Kondoa Irangi at the height of the rainy season and with grossly inadequate transport was a major error. Even had that place been as dry as claimed, it was well known that roads in the Aruscha and Moschi areas would be unusable. Instead of achieving an operational breakthrough as he had intended, he had exposed one third of his force to heavy attack while the remainder was immobile. All the forward troops suffered heavily from to malaria, with the health of van Deventer's' division being particularly seriously affected. ${ }^{70}$

The second phase began on 20 May with Smuts planning to drive south-east along the Pangani River valley, clearing the Northern Railway. Once taken, he would then move south through densely forested and mountainous areas to the Central Railway. At the same time, the Kondoa Irangi division would continue its advance south, cutting the Central Railway further to the west. $^{71}$ However, this concerted move was forestalled by the reduced condition of van Deventer's troops, who were unable to advance until mid-July, and then in a weakened state. $^{72}$ Elsewhere, the Belgians in the west and General Northey in the south-west conducted their own independent campaigns.

The main body covered nearly 130 miles in ten days under deeply difficult conditions and against weakened German rearguards. Apart from the intense heat and burning sun, the Pangani valley was covered in thick bush and difficult to traverse. The supply system, never robust, broke down and the troops were soon on half rations while sickness escalated. ${ }^{73}$ After a brief halt in early June, the columns turned south and continued the push towards the Central Railway, halting on 5 July on the Lukigura River, owing to a near collapse of the supply and transport system. ${ }^{74}$ They rested there for nearly a move, before moving again and reaching the town of Morogoro at the end of August. In the meantime, van Deventer

69

70

72

Von Lettow, My Reminiscences of East Africa, Nashville, Tennessee, nd, (reprint of 1920 original), p. 135; Hordern, Military Operations East Africa, pp. 279-280.

Macpherson, Major General Sir W G and Mitchell, Major T J, History of the Great War Based on Official Documents Medical Services General History Volume 4. Medical Services during the Operations on the Gallipoli Peninsula; in Macedonia; in Mesopotamia and North-West Persia; in East Africa; in the Aden Protectorate and in North Russia. London: HMSO, 1924, p. 438. ; ,Macpherson and Mitchell, Official History Medical Services, Volume 4, p. 438.

WO 95/5291, War Diary GHQ, 19 May 1916, Appendix 78, Telegram F 5155, Smuts to CIGS, 19 May.

Hordern, Military Operations East Africa, pp. 324-325, Note 1 "Administrative Situation of the $2^{\text {nd }}$ Division $3^{\text {rd }}$ June 1916".

Macpherson and Mitchell, Official History Medical Services, Volume 4, pp. 441 and 450.

Hordern, Military Operations East Africa, pp. 305-206. 
forced his battered command south, reaching the railway at the end of July, then pushing eastwards throughout August in an attempt to link up with Smuts.

The hallmark of this phase was the disjointed nature of the advance that enabled von Lettow to redeploy most of his forces away from van Deventer and back against Smuts. Had both British columns been able to move simultaneously, much greater pressure could have been exerted and a significant success achieved. As it was, the Germans again escaped intact, having traded empty bush for time, while the inadequate logistical situation and worsening health of the attackers was rapidly diminishing their fighting power.

In the third phase, Smuts was faced with the choice of pausing along the Central Railway and pausing to shorten his over-stretched lines of communication and rebuilding his shattered transport system. Dar-es-Salaam had been captured in early September, but owing to demolitions, it and the railway would not be full working order for several months. However, Smuts half-believed that von Lettow would passively allow himself to be surrounded and surrender thereby ending the campaign. ${ }^{75}$ He was well aware of the high sick-rate and the weakened state of his force, and somehow saw a further advance as the best means of ending the campaign quickly. He resolved to push south into the wild and virtually uncharted tropical lowland that marked the Mgeta River valley despite the imminence of the short rainy season. ${ }^{76}$

The month of September was spent with van Deventer's division moving south towards the Great Ruaha River and Smuts' main body hacking its way through jungle, mountain and swamp towards the Mgeta River. The Germans were still in good order and after inflicting a setback at Kissaki on 11 September, continued their general withdrawal south. However, the onset of heavy rain on 20 September stopped everything as rivers began to flood and dirt tracks began to dissolve into mud. ${ }^{77}$ Smuts' plan, never well-conceived, had collapsed with the supply and health situation worse than ever before. Even worse, the forward troops were in a tropical flood plain, some 40-50 miles from the still not fully functional railway separated by the most appalling lines of communication. However, realising the limitations of that approach, he did send one division by sea to the port of Kilwa where they would prepare to strike inland against the Germans. This force was subsequently attacked heavily by von Lettow at Kibata, but managed to hold firm.

The final act was Smut's offensive at the end of 1916. Conditions had improved somewhat since the ending of the rains, but the health of the troops was appalling and many had subsisted on grossly inadequate rations for many weeks. He had already taken the decision to evacuate some 12,000 of his South Africans on medical grounds, while many of the British and Indian units urgently needed repatriation. ${ }^{78}$ On receiving reinforcements from Nigeria and the Gold Coast, he decided to make one last push; this would attempt to use the main body to pin von Lettow along the Rufiji River, supported by an advance inland by the Kilwa force. ${ }^{79}$ Van Deventer was to push the enemy to the east along the Ruaha River while

\footnotetext{
75 Meinertzhagen, pp. 198; Boell, Ludwig, Die Operationen, pp. 234-235.

76 Crowe, General Smuts' Campaign, p. 197.

77 Hordern, Military Operations East Africa, p. 374.

78 Macpherson and Mitchell, Official History Medical Services, Volume 4, pp. 458-459; WO 33/858, Telegrams, No. 1333, 25 October 1916, Telegram F 5908, Smuts to CIGS. dated $28^{\text {th }}$ February 1917, published in the London Gazette" Supplement", No. 30020 of 18 April 1917, pp. 148-149. Henceforth, Smuts, Despatch III.
} 
further south Northey was to do the same over the River Ulanga. ${ }^{80}$ All had to be complete before the onset of the main rainy season.

The offensive was postponed until the very end of December, owing to rain, and began with a number of characteristic flanking moves. ${ }^{81}$ The Germans quickly abandoned the Mgeta line and withdrew to the Rufiji where eventually the British forced a crossing. While the Kilwa and other columns slowly advanced, the lack of logistic preparations and the weakened state of the troops meant than none of Smuts' objectives were fully met. No decisive battles were fought and the distances were too great and the terrain too difficult for an encirclement. Smuts' left in mid-January to attend the Imperial Conference in London, but his successor had to abandon the offensive in mid-February owing to the weather and the exhaustion of the force. ${ }^{82}$

As a means of ending the campaign, the push to the Rufiji was a failure. The Germans, although suffering badly themselves, were able to escape once more and the British were now even further from the railway and in some of the most pestilential country in the world. Less attractively and in an attempt to bolster his reputation, Smuts went on to claim a great victory and the imminent end of the fighting in East Africa, a blatant untruth that went down badly with those who had served him so loyally. ${ }^{83}$

\section{A critique of Smuts' command}

At the time, many believed that Smuts had achieved a huge and relatively inexpensive success. He had captured a great deal of ground and on the map he appeared to have beaten the Germans thoroughly. The forces under his command had taken the capital, all the major ports, both railways and some of the best farmland. But, the Schutztruppe remained undefeated, possessing both a high degree of combat effectiveness and good morale. His claims that the campaign was nearly over were subsequently rebutted by his successors' need to conduct a difficult and arduous campaign for the following year and a half. Furthermore, if he had failed to destroy the enemy's forces, his techniques had largely incapacitated his own army; over 12,000 had to be repatriated through ill-health with the unfortunate $3^{\text {rd }}$ Division only lasting four months in the field.

There is no doubt, however, that from his arrival, Smuts supplied a style of dynamic leadership that was badly needed in East Africa. He instilled a sense of drive and purpose that inspired both the staff and regimental soldier of his polyglot army. He certainly achieved what he set out to do; the acquisition of large tracts of territory with the minimum cost in battle casualties. However in doing so, the forces of disease and climate caused an enormous number of non-battle casualties that gravely weakened his force.

So Smuts, Despatch III, p. 146

$81 \quad$ Hancock and van den Poel, Selections from the Smuts Papers, 27 December 1916, Letter Smuts to Mrs Smuts, pp. 395-396, he describes the water as being waist-deep in many places; WO 95/5292, GHQ War Diary, 1 January 1917, Appendix 1, Telegram OA 443, Smuts to Adminstaff, 31 December; he was prepared to launch his offensive after just two days of dry weather.

${ }^{82}$ WO 33/858, European War Secret Telegrams Series D, Volume 1, $29^{\text {th }}$ January $1915-28^{\text {th }}$ February 1917, London: War Office, 1918, No. 1571, 15 February 1917, Telegram OA 261, Hoskins to CIGS. WO 33/858, European War Secret Telegrams Series D, Volume I, No. 1500, 11 January 1917, Telegram X 1182, Smuts to Secretary of State for War; Fendall, Brigadier General C P, The East African Force 1915 - 1919, Nashville, Tennessee: The Battery Press, 1992 (reprint of 1921 original), pp. 87-88; CAB 44/9, p. 13; MS Long, Wiltshire Record Office, Sir Charles Crewe-Long Correspondence, 22 April 1917, Letter Crewe to Long. 
There were two serious criticisms that can be levelled against Smuts' generalship; the first was his reluctance to focus on the enemy's forces and the second was the dire state in which he left his army. Regarding the first, he confessed himself to be in a hurry throughout the campaign:

"Besides we had often to hurry to get out of a deadly stretch of country or to cover a wide waterless belt, or because great and rapid moves held the promise of big prizes". 84

His political concerns, both in avoiding casualties and capturing ground, led him to set unrealistic goals that either exceeded the capabilities of his force or left it seriously underresourced. He ignored the fundamentals of military command, as stated in Field Service Regulations:

"Success in war can be attained only by the defeat of the enemy's mobile forces. The efforts of all parts of an army must be combined to that end." ${ }^{, 85}$

This sense of haste and desire to capture ground, coupled with his inexperience of staff work, led him to ignore the vital link between his Administrative and General Staffs. This failure to understand, that without a supply and transport system of sufficient capacity, lift and range, grand operational aims would inevitably founder resulted in the troops suffering immense and in many cases, preventable, hardships. It was not simply as he put it, "efforts like these cannot be made without inflicting the greatest hardships on all", 86 but a question as to whether better planning could have alleviated the worst.

As to the second criticism, it is undeniable that there were serious shortcomings in the provisioning, feeding and medical care of the force during his tenure in command, ${ }^{87}$ although he preferred to refer to the obstacles of nature rather than the inadequacies of planning. In October 1916 one of his battalion commanders lodged a formal complaint, making strong allegations of incompetence, indifference to soldiers' welfare and general negligence. ${ }^{88}$ Matters were not helped by stories beginning to emerge in the South African press claiming serious shortcomings of supply and lack of planning. ${ }^{89}$ Smuts was forced to set up a court of enquiry, which only reported in May 1917, well after his departure to London. Ultimately, it upheld the allegations of underfeeding, poor administration and lack of sufficient medical care, but conveniently found no one to blame. ${ }^{90}$

These and other reports were sufficient to concern the War Office about the true state of health and sanitation in East Africa, and in July 1917 it sent out Surgeon General Pike to make a formal investigation. ${ }^{91}$ By then van Deventer was in command, but the inspection

${ }_{84}$ Crowe, General Smuts ' Campaign, Foreword by J C Smuts, p. xii.

85 Field Service Regulations (FSR), Part II, London: War Office, 1909, p. 23.

86 Crowe, General Smuts' Campaign, Foreword by J C Smuts, pp. xii-xiii.

87 Macpherson and Mitchell, Official History Medical Services, Volume 4, p. 35.

${ }_{88}$ CO 551/101, Union of South Africa, 1917, Volume 8, Folio 38195, 31 July 1917, Court of Enquiry, Letter Lieutenant Colonel Kirkpatrick, Commanding $9^{\text {th }}$ Regiment South African Infantry to General Officer Commanding $3^{\text {rd }}$ South African Infantry Brigade, 26 October 1916, pp. 248-250. Henceforth, CO 551/101, Court of Enquiry.

Brown, James Ambrose, They Fought for King and Kaiser, Johannesburg, Ashanti Publishing, 1991, pp. 301-302. It quotes the Sunday Times of 12 November 1916.

CO 551/101, "Court of Enquiry", pp. 476-477.

CO 691/19, Tanganyika, 1917, "Confidential - Report on Medical \& Sanitary Matters in German East Africa 1917" by Surgeon General W W Pike CMG, DSO, AMS and Lieutenant Colonel A Balfour CMG RAMC. Nairobi: The Swift Press, 1918, p. 1. Hereafter, CO 691/19, Pike Report. 
was really concerned with Smuts' system and legacy. It found widespread failures in planning, co-ordination and supervision; its conclusions stated:

"When, however, all is said and done, and every allowance made for these and other drawbacks, we cannot but feel that there is much to regret in the medical history of this campaign and that a great many difficulties were due to a lack of forethought, of driving power, and of expert knowledge and assistance." 92

The Adjutant General's comments on the report were far more direct:

"Had this particular campaign been more in the public eye a very grave scandal would have resulted, owing to the want of supervision on the part of the Commander-inChief over the departments of staff concerned." 93

The question of whether Smuts was responsible for these problems is fundamental to assessing his tenure in command. He had a very forward style of command and was frequently at the front, often near the firing line, with a small personal staff. ${ }^{94} \mathrm{He}$ had comparatively few dealings with the heads of his administrative staff, preferring to concentrate on operational matters. Although unusual, such an approach was justifiable through Field Service Regulations (FSR), which governed all military operations. Part II of FSR laid out the principles concerning the authority of the commander-in-chief together with his and the staff's responsibilities in the field. It recognised that each theatre and campaign would be quite different and avoided giving categorical direction as to the exact organisation and running of a general headquarters. In order to enable the commander-in-chief to concentrate on the big picture, FSR permitted him to delegate the responsibility for administration:

"But it is a principle of war organisation that the C.-in-C. is relieved of responsibility for the conduct of the business of providing the requirements of the forces in the field, unless he sees fit to interpose." 95

The commander-in-chief had complete responsibility for all aspects of his force, including both the fighting troops and administrative services, stating that his authority was "supreme in all matters within the theatre of operations". ${ }^{96}$ It went on to specify the duties of the three staff branches, the General (GS), Adjutant General's (AG) and Quartermaster General's (QMG) as well as those of the Chief of the General Staff (CGS). The CGS was given responsibility for the co-ordination of all staff work between the branches. ${ }^{97}$ As the AG branch was largely responsible for manpower and personnel functions and the QMG responsible for the supply, equipment and transport of the force, it was clear that close coordination and planning was essential to success. However, it was up to the commander-inchief to decide how much of this co-ordinating responsibility should be delegated to his CGS and how much he retained personally; regardless of the division, this function was the sole responsibility of the GS.

To further complicate matters, the appointment of the Inspector General of Communications (IGC) existed under the supervision of the QMG. The ICG was responsible for the lines of communication and the reception, holding and transit of men and material from the base to the forward areas. The IGC could received instructions from any of

FSR, II, pp. 35-36. 
the three staff branches, but had the responsibility for organising and selecting the means of moving items forward. ${ }^{98}$

Delegation of authority did not mean abrogation, and the commander-in-chief remained responsible for all actions within his command. In practice, that meant that either he or his CGS was responsible for co-ordinating the actions of all branches and the IGC to ensure that the main administrative directors received accurate and timely information about operational intentions. ${ }^{99}$ While it was not a robust system, and had broken down on the Western Front, it could be workable given close co-operation and consultation between the commander-in-chief and his principal staff officers.

This did not happen as the senior AG staff officer noted:

"In one respect the show is being damn badly run. There is no proper co-ordination between the General Staff and the rest of the show"100

It was the same for the QMG branch as the Director of Transport later wrote:

“...the first difficulty I as D. of T. had to contend with was the absence of information as to the plans of operations, which should normally in my opinion be conveyed in sufficient time to allow of preparation of reserves in animal and mechanical transport.

Had this information been available to me, some opportunity would have been afforded to point out most of the salient transport difficulties regarding these plans and to suggest to you means of meeting such difficulties where they could be overcome...Finally that an opportunity be given to all Administrative Services to discuss the proposals of the General Staff.,"101

\section{Van Deventer's appointment}

On his departure, Smuts was succeeded by one his divisional commanders, General Hoskins, a British Regular officer. However, despite much good work in reorganising his battered force, he rapidly lost the confidence of the CIGS and subsequently the War Cabinet, and was superseded on 23 April 1917. Although it is not clear how much influence Smuts had in this decision, he was certainly involved in suggesting van Deventer as a suitable replacement. His selection as Commander-in-Chief caused a great deal of unhappiness amongst the British officers who believed it to be another political appointment.

Van Deventer appears to have had little involvement in these machinations, as he had barely a month from returning to South Africa in April 1917, before being sent back to East Africa in May. Although they had served together a number of times from the Anglo-Boer War onward, they were very different in outlook and temperament. He had much more of the professional soldier's outlook than Smuts and was not known for his politics. Van Deventer had begun his military career as a gunner in the Transvaal Artillery in 1896, rising rapidly through the ranks. A battery commander by the outbreak of war in 1899, he had served under Smuts' command during the last year of the war before retiring to his farm after the peace

\footnotetext{
$98 \quad$ FSR, II, pp. 31-32.

$99 \quad$ FSR, II, pp. 41-43.

$100 \quad$ CAB 45/44, Colonel Fendall's Diary, Entry 26 June 1916.

101 WO 95/5292, War Diary GHQ, April 1917. The War Diary enclosed "Printed Notes from War Diaries, Part CCLXXXV, EAEF Force "B", General Staff, Army Headquarters, India, April 1917, Confidential Print of Key extracts for Army Departments”. See Director Supply and Transport, East African Force, 18 to 31January 1917, Appendix A to DA\&QMG, General Headquarters, No. ST 34 dated 18 January 1917.
} 
settlement. He was recalled to service as a colonel in 1914 to participate in the South West Africa expedition, but was given the task of suppressing Maritz's troops when the Rebellion broke out in late 1914. Having completed that mission, he was promoted brigadier in command of the Upington column in the advance against German South-West Africa, finishing as a divisional commander. ${ }^{102}$

After a brief period in South Africa, he was called upon to lead a mounted brigade in East Africa under Smuts. He was rapidly promoted to command the newly-formed $2^{\text {nd }}$ Division in April 1916 which he then commanded until January 1917, when he and his troops were withdrawn to South Africa on medical grounds. After journeying back with Smuts, he had barely a month at home, before being asked to assume command of the East Africa Expeditionary Force as a lieutenant general.

\section{Van Deventer's aims and achievements}

Van Deventer had learned a great deal about the need for efficient organisation and administration during his time as a divisional commander in 1916. He was also given quite different instructions than he predecessor on arriving in East Africa on 29 May 1917. ${ }^{103}$ The CIGS came immediately to the point:

"In view of requirements other theatres and of the fact that it is essential to release at earliest possible moment vessels absorbed by supply and maintenance of your force, His Majesty's Government attach great importance to early termination of campaign. I must also impress upon you importance during remainder of campaign of limiting demands for tonnage to minimum." 104

The attitude of the British Government had changed considerably since it had so lightly sent Smuts off to take the whole of German East Africa. There was now the realisation that von Lettow had to be defeated militarily and that simple occupation of ground was not sufficient for victory. Furthermore, with the growing pressures of the U-Boat campaign and the war in Europe, it recognised that the campaign had to be wound up as quickly as possible in order to release both shipping and manpower. ${ }^{105}$

He was authorised, if necessary, to conduct operations in Portuguese East Africa, although the Portuguese themselves could be expected to give little useful assistance. Van Deventer was instructed to try to prevent the enemy from leaving German East Africa for the south as it would prolong the campaign. There was no explicit mention of any other campaign objectives, but it was clear that they implied the destruction of the enemy force and its ability to fight. ${ }^{106}$

Beyers, C J and Bu, J L Ed, Dictionary of South African Biography, Volume V, Pretoria: Human Sciences Research Council, 1987, pp. 809-810; South African National Defence Force, Personnel Archive and Reserves, AG(1) (A)P1/41391/1, Record of Service of Lieutenant General Sir Jacob Louis van Deventer in the Union Defence Force. WO 33/953, European War Secret Telegrams Series D, Volume 2, $1^{\text {st }}$ March 1917 -14th April 1919, London: War Office, 1918; No. 1868, 29 May 1917, Telegram G 666, Hoskins to CIGS. WO 33/953, European War Secret Telegrams Series D, Volume 2, No. 1852, 22 May 1917, Telegram 340907 , CIGS to van Deventer. WO 33/953, European War Secret Telegrams Series D, Volume 2, No. 1852, 22 May 1917, Telegram 340907, CIGS to van Deventer. 


\section{Van Deventer's style of command}

Van Deventer was most at home leading mounted columns, but he had learned that the difficult conditions in East Africa demanded different solutions. He was much more of a fighter than Smuts and did not shrink from battle. His methods were direct and he certainly could not be described as an administrator, but he did use his staff more effectively. One British officer described him:

"Van Deventer is calm and collected, divulging his plans to none, not even his staff. $\mathrm{He}$ is cunning as an old fox and does not make up his mind till the last moment. Then he acts like lightening; up to that moment he appears dense and slow. To him a decision is final; there is no swerving, no delay, no alteration of plan."107

He believed in using mounted and irregular troops whenever possible although he recognised the limitations imposed by the tsetse fly. He had realised the futility of trying to out-manoeuvre the Germans in such difficult terrain and that they had to be defeated militarily. Also important was his recognition that their chief vulnerabilities were lack of replacement manpower together with low stocks of food and munitions. Disease remained the deadliest foe, but better planning and support for the troops could help reduce its illeffects.

These factors led van Deventer to adopt a much more aggressive approach together with greater tactical ingenuity. While the power of the machine gun and the strength of defensive works meant that the casualties would generally be higher for the attacker than the defender, he also realised that attrition could be an effective option. However restricted his manpower and equipment reserves were, they were still vastly superior to those of von Lettow, particularly in European officers and NCOs. Accordingly, this led to a new strategy of hard-hitting wherever possible with the aim of inflicting the maximum casualties while lowering morale and the will to continue. It was combined with a campaign against the German lines of communication, and in particular eliminating their food growing areas. ${ }^{108}$

\section{Van Deventer's operational achievements}

Van Deventer spent the most time as commander-in-chief in East Africa and it may be divided into four major parts; the first was the concentric advance towards the Lukuledi River (June to September 1917); the second was the clearance of the southern portion of German East Africa (November 1917 to January 1918); the third was the pursuit through northern Portuguese East Africa (February to May 1918); and the fourth was the clearance of Portuguese East Africa and the end of the campaign (June to November 1918).

The first part of van Deventer's command was spent in clearing the central part of German East Africa. This was not an easy task as the Germans retained interior lines in a territory some 300 miles square and difficult to penetrate. ${ }^{109} \mathrm{He}$ launched a series of concentric attacks from widely separated locations with the aim of driving the enemy into a concentrated position where he could be decisively engaged. The main forces advanced from Kilwa and Lindi, supported by the Belgians in the west and Northey in the south. The Kilwa force advanced slowly south, fighting several pitched battles en-route, while the Lindi force

\footnotetext{
$107 \quad$ Meinertzhagen, Army Diary, p. 180.

108 WO 33/953, European War Secret Telegrams Series D, Volume 2, No. 1901, 11 June 1917, Telegram G 843, van Deventer to CIGS. 
made a difficult and complicated breakout of its enclave. By the end of August, the strategy was broadly successful and the scattered columns were beginning to converge. These operations were marked by the return of mounted units to East Africa and their use against the enemy lines of communications in the many tsetse fly-free areas found in the south. ${ }^{110}$ They also demonstrated the new aggressiveness and determination to attack the enemy. Although there were several unsuccessful engagements, the policy of hard-hitting and food denial forced the Germans back while clearing large areas of farming country.

In September, van Deventer instigated a major drive to outflank and then hit the German main body west of Lindi. ${ }^{111}$ This culminated in the major battle at Mahiwa in early October, in which each side lost nearly a quarter of their force. The results of the battle forced the British to call a temporary halt while the Germans were able to prepare for the defence of the last remaining portion of their colony. ${ }^{112}$ Following the halt after Mahiwa, van Deventer continued the pressure, with the over-riding aim of preventing the Germans from escaping into Portuguese East Africa. The Kilwa and Lindi forces were now merged, with continuing effective support from Northey and the Belgians. During the month of November, the advance continued at high speed with a series of engagements being fought and large number of German captives and deserters being taken. It culminated at the end of the month with the surrounding and capture of half the remaining enemy force. ${ }^{113}$ Through determination and a degree of good luck, a much-weakened von Lettow managed to escape south into Portuguese territory at the end of November.

The second phase was most successful in turning the Germans out of a number of very strong positions and attacking their lines of communications. It also marked the end of their fighting power as a serious force and the total clearance of the colony. The escape of von Lettow was unfortunate and really made possible by the incapacity of the Portuguese forces facing him.

The third phase comprised the immediate follow-up of von Lettow into Portuguese East Africa with the concurrent preparation for a campaign in the next dry season. Despite the coming of the rains, van Deventer launched two well-equipped columns to harry the enemy from the coast and Nyasaland respectively. ${ }^{114}$ Although not strong enough to defeat the Schutztruppe, these columns maintained pressure and had made life difficult for the Germans forcing them to abandon a number of fertile areas that had been used for growing crops. In the meantime, reinforcements were raised and extensive preparations for the coming offensive were made. Throughout the period, the British effort was handicapped by the inability of the Portuguese to stop the Germans from seizing territory or preventing vital supplies from falling into their hands. ${ }^{115}$

In the circumstances, van Deventer achieved as much as he could have expected. The advanced columns inflicted a number of blows at Korewa and Luambala and a certain degree

\footnotetext{
110 WO 33/953, European War Secret Telegrams Series D, Volume 2, No. 1987, 16 July 1917, Telegram G 346, van Deventer to War Office.

WO 33/953, European War Secret Telegrams Series D, Volume 2, No. 2141, 10 September 1917, Telegram G 176, van Deventer to CIGS. Telegram 690, van Deventer to CIGS. Telegram 2091 W, Base Adjutant to War Office. In the month of November, the British captured some 1273 European and 3153 African prisoners. 
of discouragement amongst the German Askaris. The wet weather permitted only relatively small-scale operations, but he did use the time to build up stocks for the dry season.

The fourth and final phase of operations saw the deployment of the full British force in a series of concentric moves against a highly mobile and elusive Schutztruppe. Following a disaster at Nhamacurra in June, van Deventer relegated the Portuguese to the coastline and spent most of the period trying to hit von Lettow. ${ }^{116}$ Several heavy battles were fought at Regone and Lioma with the honours being drawn, but each inflicted significant and irreplaceable losses on the Germans. ${ }^{117}$ Finally, in September, they managed to break away from the British columns, who had reached the limit of their supply lines, and escaped first into German East Africa and then to Northern Rhodesia when the war ended. Van Deventer was in hot pursuit, but the Germans ended undefeated.

In this period, van Deventer came close to victory on several occasions, but just missed it owing to subordinates' bad judgement, the terrain and occasional bad luck. He continued to reduce both the morale, despite von Lettow's latter assertions, and the fighting strength of the Germans, who numbered less than 1,500 at the end. He had pushed his troops very hard, but his careful logistic preparations, particularly road building had paid off. Rations were often delayed, but there were no repetitions of the awful conditions that besmirched late 1916 and early 1917. Although he was unable to end the campaign in East Africa as instructed, he had maintained the initiative and had cleared Portuguese East Africa of the enemy.

\section{A critique of Van Deventer's command}

Van Deventer conducted the campaign much more in the manner of a professional soldier than Smuts. His experiences of the preceding year had shown him the folly of simply trying to capture territory and the absolutely critical need for an efficient system of logistics. Consequently, he was prepared to delay moves in order to build up adequate stocks of supplies although when the opportunity presented itself, he was just as capable as Smuts in demanding tremendous efforts on reduced rations.

From the outset, he adopted a dual strategy of attrition and food denial that was to prove ultimately successful. Although his forces were never plentiful, he realised von Lettow was much more vulnerable in this regard and it was a weakness to be exploited. Likewise, once he found himself operating in areas free of the tsetse fly he re-introduced mounted forces that operated to great effect. He also used his scouts and irregulars to foment antiGerman revolts. Largely unnoticed, was the vast amount work that he directed on road making, which eased his supply difficulties considerably. The northern portion of Portuguese East Africa was virtually a trackless expanse at the end of 1916; by war's end it was possible to drive a car from Lindi to Quelimane.

The greatest factor that denied him success was the performance of the allied Portuguese forces. Despite trying to stop the Germans, their ineptitude gave von Lettow the opportunity he needed to carry on the campaign on repeated occasions. On the other hand, he did have a tendency to over-control and at times gave far too many detailed instructions to column commanders operating in barely mapped bush. In his keenness to end the campaign, he occasional committed too many troops to elaborate moves; apart from complicating 
matters, it also put too great a strain on the supply system and restricted the range of key columns.

\section{Summary - Smuts and Van Deventer compared}

In comparing Smuts and van Deventer as commanders-in-chief, it should be noted that both had quite different tasks and each interpreted his instructions in his own way. First of all, Smuts was instrumental in securing both an aggressive policy in East Africa as well as ensuring significant South African participation. However, he was much more interested in seizing territory than defeating the Germans in battle and underestimated the perils of the climate. This led to a rushed and inadequately prepared campaign that dragged out much longer than expected.

Smuts was personally brave and drove himself as well as his subordinates very hard, but seems to have believed that sheer strength of will could overcome all material difficulties. In an unhealthy tropical climate with poor communications, this was manifestly not the case and the bulk of his army was eventually incapacitated through disease, overwork and underfeeding. The capture of thousands of square miles of bush and swamps was achieved at very high price in human and animal health. Despite his undoubted intellect, he never really grasped the fundamental need to match operational desires with the realities of logistics. Continually forward with a small personal staff, his command style relied heavily on an efficient staff supporting him. Unfortunately, his failure to consult his Administrative Staff sufficiently or to ensure adequate briefings were carried out resulted in major failures in the supply, transport and medical services. This was typified by his reluctance to seek advice or to even to confer with key officers outside of the GS.

Smuts believed that his long marches and deep flanking moves were highly successful despite the cost in sickness and debility. In fairness, it is true that they did accomplish his goals. However, those aims were not consistent with military success for as long as the Schutztruppe's morale and fighting power remained intact, the campaign could not be ended. Until the end of his command, he maintained a half-belief that if von Lettow were cornered that he would quietly surrender. Smuts had difficulty in dealing with this; on the one hand, he recognised the need for a prolonged campaign and on the other, he would make illprepared lunges that resulted in the exhaustion and semi-starvation of his troops without beating von Lettow.

Although a loyal subordinate of Smuts, van Deventer had a very different outlook to fighting and was faced with a very different situation. London finally realised that Smuts had been wildly over-optimistic and that the conquest of German East Africa was very was no easy "mopping-up" task. He had to fight a full campaign against a professional enemy who remained strong and determined to hold on. Van Deventer realised that the combat power of the Schutztruppe had to be destroyed as quickly as possible. To that end, he adopted a dual approach of hitting the enemy hard whenever possible while concurrently trying to deny them access to food supplies. With superior manpower and equipment reserves, he used attrition, particularly of the irreplaceable German leaders, to weaken both fighting power and morale. The result of this strategy was that by the end of 1917, the whole of German East Africa had been occupied, but most importantly, the enemy's fighting strength had dropped from 8,000 to less than 2,000 .

As a commander-in-chief, van Deventer chose to follow the more conventional approach of remaining at General Headquarters for the bulk of his time, going forward for 
periodic visits. This ensured much better co-ordination with the staff, but also let him take the bigger picture without being drawn into local engagements. While the margin of safety was always narrow, the standard of administration and care for the troops also increased significantly. There was no repetition of the shocking shortfalls of food and equipment that so marked 1916 and early 1917.

Van Deventer was aggressive and remained remarkably consistent in his approach. Typical was his refusal to let up the pursuit of von Lettow during the rains of early 1917; he ensured that two small, but well equipped columns operated out of Port Amelia and Nyasaland while he prepared the main force for major operations in the dry season. He did have a tendency to over-control and occasionally gave too much direction as occurred in June and July 1918. However, he gave the enemy no rest and was in hot pursuit up until the Armistice. That he never captured or destroyed the remnants of the Schutztruppe was due to a combination of bad luck and lack of Portuguese military competence; he came close on several occasions, but von Lettow managed to escape.

In all, the two South African commanders-in-chief had differing goals and by their standards, largely achieved them. However, if the standard of military success is victory on the battlefield then it is difficult to judge Smuts a success. While he captured a great deal of territory, he never seriously threatened the existence of his enemy and left the theatre with their morale and fighting power unharmed. On the debit side, he had to evacuate the bulk of his army through ill-health and those who were left were in no condition to carry on the advance. In the end, it took substantial reinforcements, rest and re-equipment before the East African Expeditionary Force was ready to take the battle to the Germans.

Van Deventer was given the mission of ending the campaign as rapidly as possible. In this he failed, as von Lettow did not surrender until after the signing of the Armistice. However, he achieved a number of successes in the field, reducing his opponents to little more than a band of weakened companies and enabling the withdrawal of a large number of his own units. His policy of attacking the enemy's food supplies was a sound one and hastened the end of resistance in German East Africa as well as the surrender of large numbers of fighting troops. Attrition, so discredited elsewhere, was an effective policy under the circumstance in East Africa, and came close to finishing the campaign.

Both men faced a highly capable opponent plus extreme difficulties of climate, terrain and disease that would have daunted any regular officer. Each tried very hard to accomplish his mission, although with very different methods and styles. Smuts captured a great deal of German East Africa in relatively short order, but at the cost of crippling his own forces. Van Deventer also occupied a considerable amount of enemy territory, but also broke the back of the Schutztruppe as a fighting force in 1917 and carried on an aggressive campaign throughout 1918. He too suffered a number of losses, but maintained a mobile and hard hitting force until the end of the war. In the final analysis, although Smuts was well known and lauded for his exploits, van Deventer must be considered the better general. 